\title{
COMMUNICATION
}

\section{EFFECT OF PLANT AND FUNGOUS METABOLITES ON Meloidogyne exigua}

\author{
Efeito de metabólitos vegetais e fúngicos sobre Meloidogyne exigua
}

\author{
Daniel Rufino Amaral ${ }^{1}$, Denilson Ferreira Oliveira ${ }^{2}$, Vicente Paulo Campos ${ }^{3}$, \\ José Antônio Pantaleão ${ }^{4}$, Douglas Antônio de Carvalho ${ }^{5}$, Alexandro da Silva Nunes ${ }^{6}$
}

\begin{abstract}
As nematodes cause great damage to Brazilian coffee production, effective methods to control these parasites are necessary. In a previous work Allium cepa L., Cajanus cajan (L.) Mill., Crotalaria juncea L., Ficus elastica Roxb., Ruta graveolens L., Stylosanthes guianensis Aubl., Leucaena leucocephala (Lam.) Dewit., Brachiaria decumbens Stapf., Catharanthus roseus G. Don, Tagetes minuta L., Ricinus communis L. and Coffea arabica L. produced active substances against Meloidogyne exigua Goeldi, a nematode widely disseminated through Brazilian coffee fields. Thus, aqueous extracts of such plants, collected in a different season from that of the previous work, as well as crude metabolites produced in liquid medium by Fusarium moniliforme Shelden and Cylindrocarpon magnusianum (Sacc.) Woll., were submitted to in vitro assays with M. exigua second-stage juveniles (J2). All plants and fungi produced active substances against J2. Therefore, their metabolites were applied to six-month-old coffee plants inoculated with M. exigua. After 90 days in a greenhouse, those samples obtained from A. cepa, L. leucocephala, $R$. graveolens and $F$. moniliforme inhibited the production of galls and eggs by M. exigua, demonstrating potential to control such parasite.
\end{abstract}

Index terms: Fungi, Heteroderidae, nematicide, plant extract, Tylenchida.

\section{RESUMO}

Os nematóides acarretam grandes perdas aos produtores brasileiros de café, sendo necessário o desenvolvimento de métodos eficientes para o seu controle. Em trabalho anterior, Allium cepa L., Cajanus cajan (L.) Mill., Crotalaria juncea L., Ficus elastica Roxb., Ruta graveolens L., Stylosanthes guianensis Aubl., Leucaena leucocephala (Lam.) Dewit., Brachiaria decumbens Stapf., Catharanthus roseus G. Don, Tagetes minuta L., Ricinus communis L. e Coffea arabica L. produziram substâncias ativas contra o nematóide Meloidogyne exigua Goeldi, que é amplamente disseminado pelos cafezais brasileiros. Dando continuidade a esse trabalho, extratos aquosos das plantas mencionadas, coletadas em época diferente daquela mencionada no trabalho anterior, bem como metabólitos na forma bruta de Fusarium moniliforme Shelden e Cylindrocarpon magnusianum (Sacc.) Woll., produzidos em meio de cultura líquido, foram submetidos a testes in vitro com juvenis do segundo estádio (J2) de M. exigua. Todas as plantas e fungos produziram substâncias ativas contra J2. Portanto, seus metabólitos foram aplicados em mudas de café de seis meses de idade, inoculadas com M. exigua. Após 90 dias em casa de vegetação, verificou-se que os materiais oriundos de A. cepa, L. leucocephala, R. graveolens e F. moniliforme inibiram a produção de ovos e de galhas por M. exigua, demonstrando potencial para o controle de tal parasita.

Termos para indexação: Extrato vegetal, fungos, Heteroderidae, nematicida, Tylenchida.

\section{(Received in march 5, 2007 and approved in august 27, 2007)}

Apparently, the total number of nematodes may reach millions (LEY, 2000). Some of them cause severe agricultural damages, as observed in Brazilian coffee production, which faces about US\$ 1 billion loss per year (SANTOS, 2000). This makes the development of more efficient methods for nematode control in coffee fields greatly needed.
Meloidogyne exigua Goeldi (Tylenchida:Heteroderidae) is one of the nematodes found in Brazilian coffee plantations. It is distributed throughout the country, including areas contaminated with other nematode species (CAMPOS \& VILLAIN, 2005). Although there are several approaches to control such nematode, they are not very useful in coffee fields, making the use of commercial nematicides the

'Engenheiro Agrônomo, Doutor, Professor - Faculdade de Engenharia de Passos/FEP - Fundação de Ensino Superior de Passos/FESP - 37.200-106 Passos, MG - danielrufino78@yahoo.com.br

${ }^{2}$ Químico, Doutor, Professor - Departamento de Química/DQI - Universidade Federal de Lavras/UFLA - Cx. P. 3037 - $37200-000$ - Lavras, MG denilson@ufla.br

${ }^{3}$ Engenheiro Agrônomo, PhD, Professor - Departamento de Fitopatologia/DFP - Universidade Federal de Lavras/UFLA - Cx. P. 3037 - $37200-000$ Lavras, MG - vpcampos@ufla.br

${ }^{4}$ Engenheiro Agrônomo - Avenida José Cambraia, 182 - Centro - 38950-000 - Ibiá, MG - zepantaleao@hotmail.com.

${ }^{5}$ Engenheiro Agrônomo, Doutor, Professor - Departamento de Biologia/DBI - Universidade Federal de Lavras/UFLA - Cx. P. 3037 - $37200-000$ - Lavras, MG douglasc@ufla.br

${ }^{6}$ Químico, Mestrando em Agroquímica - Departamento de Química/DQI - Universidade Federal de Lavras/UFLA - Cx. P. 3037 - $37200-000$ - Lavras, MG sanquimica@ig.com.br 
preferred method to solve the problem (CAMPOS, 1999). As the use of such products has caused human and environmental contamination with toxic substances, several studies have been conducted to develop low toxicity substances for nematode control. A promising possibility resides on natural products such as plant and fungous metabolites.

The co-existence of fungi and nematodes in the same habitat probably induced the production of metabolites by the former organisms to be used in attack or defense against nematodes. There are several examples of such substances in literature (SALGADO et al., 2007; SILVA et al., 2008; COSTA et al., 2001a,b; INSUNZA et al., 2001; KIMURA et al., 1996), among them is aspyrone, produced by Aspergillus melleus Yukawa. During experiments in vitro, a $100 \mu \mathrm{g} / \mathrm{mL}$ solution of such substance caused $39 \%$ mortality of Pratylenchus penetrans (Cobb) Chitwood \& Oteifa (KIMURA et al., 1996).

Plants also produce nematicide substances (COSTA et al., 2001a; FERRAZ \& VALLE, 1997), and some of them have been purified and identified. An example is asparagusic acid, isolated from Asparagus sp, active against Pratylenchus curvitatus Van der Linde, Pratylenchus penetrans Cobb, Heterodera rostochiensis Woll., Heterodera glycines Ichinohe and Meloidogyne hapla Chitwood (TAKASUGI et al., 1975).

In a previous work several plant extracts were used for assays in vitro with $M$. exigua second stage juveniles (J2) (AMARAL et al., 2002). The most promising extracts, obtained from Allium cepa L. and Ruta graveolens L., were also employed in experiments with six-month-old coffee plants inoculated with $M$. exigua, prompting reduction of gall number without any toxic effect on coffee plants. Since stage of plants may influence their extract characteristics (HARBORNE, 1998), in this study all species were collected in the summer (in the previous work plants were collected in the spring) to check out whether their in vitro nematicide activity could vary with the season. Additionally, all extracts were submitted to an assay with coffee plants to find out their effect on gall and egg number of M. exigua.

Analogously, some crude fungi metabolites had already been submitted to tests with Meloidogyne incognita (Kofoid \& White) Chitwood, which allowed the identification of some nematicide producing microorganisms (COSTA et al., 2001b). To find out whether they could be useful in $M$. exigua control, two of these fungi were also employed in this study.

To prepare plant extracts, parts $(25 \mathrm{~g})$ of the following plants, collected at Universidade Federal de
Lavras, in Brazil, on July 2003, were cut into small pieces and immersed in $500 \mathrm{ml}$ boiling distilled water: bulbs of peeled onion (Allium cepa L. cv. Pira ouro), leaves of pigeon pea (Cajanus cajan (L.) Mill.), sunn hemp (Crotalaria juncea L.), rubber tree (Ficus elastica Roxb.), rue (Ruta graveolens L.), stylo (Stylosanthes guianensis Aubl.), white lead tree (Leucaena leucocephala (Lam.) Dewit.), signal grass (Brachiaria decumbens Stapf.), periwinkle (Catharanthus roseus G. Don), marigold (Tagetes minuta L.) and castor bean (Ricinus communis L.) and freeze dried coffee husk (Coffea arabica L. cv. Mundo Novo). After cooling at room temperature, the resulting mixtures were filtrated through filter paper (Whatman number 1) and employed in the assays.

For fungi metabolites preparation, cultures of Fusarium moniliforme Shelden and Cylindrocarpon magnusianum (Sacc.) Woll., were grown in Czapek-Dox medium $\left(0.5 \mathrm{~g} \mathrm{KCl}, 1 \mathrm{~g} \mathrm{K \textrm {KH } _ { 2 }} \mathrm{PO}_{4}, 2 \mathrm{~g} \mathrm{NaNO}, 30 \mathrm{~g}\right.$ sucrose, $0.01 \mathrm{~g} \mathrm{FeSO}_{4} .7 \mathrm{H}_{2} \mathrm{O}$ and $0.5 \mathrm{~g} \mathrm{MgSO}_{4}$ per $1,000 \mathrm{ml}$ distilled water) during 23 days, at $25^{\circ} \mathrm{C}$, under constant stirring and with no light incidence. The mixtures were filtrated through filter paper (Whatman number 1 ) and $0.22 \mu \mathrm{m}$ membranes, and the resulting filtrates were employed in the assays.

Eggs of M. exigua were obtained from coffee plants (C. arabica) in accordance with the Hussey \& Barker's technique, modified by Boneti \& Ferraz (1981). Their roots were cut in small pieces $(2 \mathrm{~cm})$ and triturated in a mixer with a $0.5 \% \mathrm{NaClO}$ aqueous solution during 30 seconds. Then, the mixture was filtrated through 20, 200 and 500 mesh (in/ $\mathrm{cm}^{2}$ ) sieves to collect the eggs, which were washed out of the sieves with distilled water.

Meloidogyne exigua second-stage juveniles (J2) were hatched from the eggs in a Baermann funnel (DUNN, 1969), collected and used. Less than 2-day-old J2 were employed in the assays in vitro. Twenty $\mu \mathrm{l}$ of an aqueous suspension with approximately $25 \mathrm{~J} 2$ and $100 \mu \mathrm{l}$ of plant extract or fungous filtrate, were placed in each $300 \mu \mathrm{l}$ well of a 96-wells polypropylene plate (SILVA, 2001). After $24 \mathrm{~h}$, $\mathrm{J} 2$ were separated by filtration through a 500 mesh $\left(\mathrm{in} / \mathrm{cm}^{2}\right)$ sieve and suspended in distilled water. All $\mathrm{J} 2$ were counted $24 \mathrm{~h}$ later and those with no mobility were considered dead. Distilled water $(100 \mu \mathrm{l})$ and $150 \mu \mathrm{g} / \mathrm{mL}$ Aldicarb solution $(100 \mu \mathrm{l})$ was used as negative and positive controls, respectively. This experiment was performed with six replicates per treatment. All values of dead J2 were converted to percentage prior to statistical calculations.

To evaluate plant and fungous metabolite effects on egg and gall numbers in coffee roots, six-month-old coffee plants ( $C$. arabica cv. Catuaí) were planted in $3 \mathrm{~L}$ pots containing $\mathrm{CH}_{3} \mathrm{Br}$ treated sand and soil substrate (2:1), 
which was fertilized with 4:14:8 (NPK). The plants were inoculated with 2,000 M. exigua eggs $(20 \mathrm{ml}$ aqueous suspension) and treated with $20 \mathrm{~mL}$ of plant extracts or fungous filtrate, which were applied near to the roots. This experiment was carried out in a randomized block design (6 blocks) and plants inoculated with $M$. exigua and treated with $20 \mathrm{ml}$ of a $500 \mu \mathrm{g} / \mathrm{mL}$ Aldicarb aqueous solution was employed as control. After 90 days in a greenhouse, plants were removed from the pots and their roots were carefully washed with water. Galls were counted and the roots were cut into $2 \mathrm{~cm}$ pieces and triturated in a mixer with a $0.5 \%$ $\mathrm{NaClO}$ solution during $30 \mathrm{~s}$. The resulting mixtures were filtrated through 20, 200 e $500 \mathrm{mesh}\left(\mathrm{in} / \mathrm{cm}^{2}\right)$ sieves and the eggs were washed out of the sieves with water (BONETI \& FERRAZ, 1981). M. exigua eggs were counted in the resulting suspension in an inverted lens microscope.

SISVAR software was employed for the statistical analyses, which were carried out after transforming gall and egg numbers into $(x+1)^{1 / 2}$ to achieve variance homogeneity. The resulting values and percentage of dead $\mathrm{J} 2$ were individually submitted to analysis of variance (ANOVA) and means were separated according to the Scott-Knott test (SCOTT \& KNOTT, 1974) ( $\mathrm{p} \leq 0.05)$.

All plant extracts presented in vitro activity against M. exigua (Table 1), being the best results obtained with $A$. cepa, $R$. communis and $R$. graveolens, which afforded dead $\mathrm{J} 2$ in greater amounts than the Aldicarb solution. The effect of the C. arabica extract was statistically identical to the nematicide one and the treatments with the remaining extracts presented lower values.

The results of the in vitro experiments (Table 1) were in accordance with a previous work (AMARAL et al., 2002), which was carried out with plants collected in the spring. It suggests that plant stage do not have great influence on nematicide production by those species used in this study.

The most promising plant extracts in $M$. exigua inoculated coffee plants were those prepared from $R$. graveolens, A. cepa and L. leucocephala. Although the numbers of galls per root were statistically identical to the one observed for Aldicarb, such plant extracts afforded lower egg numbers per root than that nematicide (Table 1). The $C$. cajan extract was statistically identical to Aldicarb, while the others plant extracts only reduced the number of galls. Actually, the extracts of $C$. juncea, R. communis, $B$. decumbens, F. elastica, T. minuta and S. guianensis increased the number of eggs.

The antagonist action of A. cepa, L. leucocephala and $R$. graveolens against plant parasite nematodes is known. For example, L. leucocephala extract reduced the number of $M$. incognita eggs in tomato plants (COSTA et al., 2001a). The extract of $R$. graveolens was active against

Table 1 - Effect of plant extracts and fungous filtrates on Meloidogyne exigua second-stage juveniles (J2) in vitro and on formation of galls and eggs in coffee plants inoculated with that nematode.

\begin{tabular}{|c|c|c|c|}
\hline Treatment & In vitro dead $\mathrm{J} 2(\%)^{*}$ & Galls/root* & Eggs/root* \\
\hline Water & $2 a$ & $24 \mathrm{~d}$ & $170 \mathrm{~b}$ \\
\hline C. magnusianum & $39 \mathrm{~b}$ & $18 \mathrm{~b}$ & $274 \mathrm{c}$ \\
\hline C. juncea & $45 \mathrm{~b}$ & $20 \mathrm{c}$ & $221 \mathrm{c}$ \\
\hline S. guianensis & $47 \mathrm{~b}$ & $16 \mathrm{~b}$ & $148 \mathrm{~b}$ \\
\hline B. decumbens & $52 \mathrm{c}$ & $21 \mathrm{c}$ & $232 \mathrm{c}$ \\
\hline F. elastica & $55 \mathrm{~d}$ & $14 \mathrm{~b}$ & $228 \mathrm{c}$ \\
\hline C. cajan & $58 \mathrm{~d}$ & $11 \mathrm{a}$ & $138 \mathrm{~b}$ \\
\hline T. minuta & $62 \mathrm{e}$ & $16 \mathrm{~b}$ & $250 \mathrm{c}$ \\
\hline L. leucocephala & $63 \mathrm{e}$ & $8 \mathrm{a}$ & $84 \mathrm{a}$ \\
\hline C. arabica & $71 \mathrm{f}$ & $14 \mathrm{~b}$ & $182 \mathrm{~b}$ \\
\hline Aldicarb & $76 \mathrm{f}$ & $11 \mathrm{a}$ & $112 \mathrm{~b}$ \\
\hline$R$. graveolens & $82 \mathrm{~g}$ & $7 \mathrm{a}$ & $57 \mathrm{a}$ \\
\hline R. communis & $86 \mathrm{~g}$ & $21 c$ & $255 \mathrm{c}$ \\
\hline A. сера & $88 \mathrm{~g}$ & $9 \mathrm{a}$ & $72 \mathrm{a}$ \\
\hline F. moniliforme & $91 \mathrm{~g}$ & $9 \mathrm{a}$ & $97 \mathrm{a}$ \\
\hline $\mathrm{CV}(\%)$ & 7 & 27 & 28 \\
\hline
\end{tabular}

*Within a column, means with the same letter do not differ significantly according to the Scott-Knott test $(\mathrm{p} \leq 0.05)$. 
Xiphinema americanum Cobb, an economically important pathogen in grapevine (INSUNZA et al., 2001), while $A$. cepa extract was active against $M$. exigua in experiments with coffee plants (AMARAL et al., 2002), reducing the number of galls in six-month-old plants. In addition, this plant was able to produce active carbohydrates against nematodes (AMARAL et al., 2003).

Stylosanthes guianensis and C. arabica extracts yielded poorer results than the one obtained with the commercial nematicide aldicarb (Table 1). According to Ferraz \& Valle (1997) e Sharma et al. (1994), S. guianensis could control $M$. javanica in green-house experiments. Analogously, $C$. arabica extracts could control $M$. incognita in tomato plants kept in a greenhouse (COSTA et al., 2001a).

The extract of $T$. erecta, about which there are evidences of antagonist activity to nematodes in field and greenhouse experiments with tomato, bean, pepper, eggplant, soya, corn and citrus (FERRAZ \& VALLE, 1997), was not able to control M. exigua.

Although B. decumbens, R. communis and $C$. juncea are mentioned as nematode antagonist (COSTA et al., 2001a; FERRAZ \& VALLE, 1997), no effect of their extracts against the formation of $M$. exigua galls and eggs was observed.

Fusarium moniliforme metabolites caused $91 \% \mathrm{~J} 2$ deaths, while those ones produced by $C$. magnusianum caused only $39 \%$ deaths (Table 1), which was statistically higher than the value obtained with the negative control (distilled water). Such results are similar to those obtained by Costa et al. (2001b) against $M$. incognita. During the experiment with coffee plants, the effect of the $F$. moniliforme filtrate was statistically identical to that of Aldicarb, while C. magnusianum filtrate was inefficient, since it slightly reduced the number of galls and strongly increased the number of eggs (Table 1). The nematicidal activity of the $F$. moniliforme filtrate in coffee plants was expected, since it was reported in a previous work with $M$. incognita in tomato (COSTA et al., 2001b).

Either for plants or fungi, no general rule could be built to relate the in vivo and the assays in vitro. $R$. communis and $B$. decumbens extracts, for example, presented the best results regarding $\mathrm{J} 2$ mortality, but their effects on $M$. exigua in coffee plants were not comparatively satisfactory (Table 1).

Concluding, the extracts of $R$. graveolens, $L$. leucocephala and $A$. cepa and the filtrate of $F$. moniliforme were the most effective to control $M$. exigua in coffee plants, inhibiting the formation of galls and eggs of that nematode to a higher extent than the nematicide Aldicarb.
The $C$. cajan extract also presented potential for nematode control, since it performed similarly to Aldicarb. Further studies must be carried out to evaluate the usefulness of these organisms in such area.

\section{AKNOWLEDGEMENTS}

The authors thank Fundação de Amparo à Pesquisa do Estado de Minas Gerais -(FAPEMIG) and Programa Nacional de Pesquisa e Desenvolvimento do Café (PNP\&D- Café) for financial support and for fellowships.

\section{REFERENCES}

AMARAL, D. R.; OLIVEIRA, D. F.; CAMPOS, V. P.; CARVALHO, D. A. Efeito de alguns extratos vegetais na eclosão, mobilidade, mortalidade e patogenicidade de Meloidogyne exigua do cafeeiro. Nematologia Brasileira, Brasília, v. 26, n. 1, p. 43-46, 2002.

AMARAL, D. R.; OLIVEIRA, F. E. R.; OLIVEIRA, D. F.; CAMPOS, V. P. Purification of two substances from bulbs of onion (Allium cepa L.) with nematicidal activity against Meloidogyne exigua Goeldi. Nematology, Leiden, v. 5, n. 6, p. 859-864, 2003.

BONETI, J. I. S.; FERRAZ, S. Modificação do método de Hussey e Barker para extração de ovos de Meloidogyne exigua de cafeeiro. Fitopatologia Brasileira, Brasília, v. 6, n. 3, p. 553, 1981.

\section{CAMPOS, V. P.Manejo de doenças causadas por fitonematóides. Lavras: UFLA, 1999. v. 1, 106 p.}

CAMPOS, V. P.; VILLAIN, L. Nematode parasites of coffee and cocoa. In: LUC, M.; SIKORA, R. A.; BRIDGE, J. (Eds.). Plant parasitic nematodes in subtropical and tropical agriculture. 2. ed. London: CAB, 2005. p. 529-579.

COSTA, M. J. N.; CAMPOS, V. P.; OLIVEIRA, D. F. Toxidade de extratos vegetais e de estercos a Meloidogyne incognita. Summa Phytopatologica, Jaboticabal, v. 27, n. 2, p. 22-23, 2001a.

COSTA, M. J. N.; CAMPOS, V. P.; PFENNING, L. H.; OLIVEIRA, D. F. Toxidade de filtrados fúngicos a Meloidogyne incognita. Fitopatologia Brasileira, Brasília, v. 26, n. 4, p. 54-56, 2001 b.

DUNN, R. A. Extraction of cysts of Heterodera glycines from soils by centrifugation in high density solutions. Journal of Nematology, Ames, v. 1, n. 1, p. 7-17, 1969. 
FERRAZ, S.; VALLE, L. A. C. Controle de itonematóides por plantas antagônicas. Viçosa: UFV, 1997. 68 p.

HARBORNE, J. B. Phytochemical methods. London: Chapman \& Hall, 1998. 288 p.

INSUNZA, B. V.; ABALLAY, E.; MACAYA, J. In vitro nematicidal activity of aqueous plant extracts on Chilean populations of Xiphinema americanum sensu lato. Nematropica, Florida, v. 31, n. 1, p. 47-54, 2001.

KIMURA, Y.; NAKAHARA, S.; FUJIKOKA, S. Aspyrone, a nematicidal compound isolated from the fungus Aspergillus mellus. Bioscience Biotechnology and Biochemistry, Toquio, v. 60, n. 11, p. 1375-1376, 1996.

LEY, P. D. Lost in worm space: phylogeny and morphology as road maps to nematode diversity. Nematology, Leiden, v. 2, n. 1, p. 9-16, 2000.

SALGADO, S. M. de L.; RESENDE, M. L. V.; CAMPOS, V.P. Efeito de indutores de resistência sobre Meloidogyne exigua do cafeeiro. Ciência e Agrotecnologia, Lavras, v.31, n.4, p.1007-1013, jul./ago., 2007.

SANTOS, J. M. Fatos e efeitos relevantes na história da nematologia no Brasil e principais desafios para o início do novo século. In: CONGRESSO BRASILEIRO DE
NEMATOLOGIA, 22., 2000, Uberlândia, MG. Anais... Uberlândia: UFU, 2000. p. 9-13.

SCOTT, A. J.; KNOTT, M. Cluster analysis method for grouping means in the analysis of variance. Biometrics, Raleigh, v. 30, n. 3, p. 507-512, 1974.

SILVA, P. A.; OLIVEIRA, D. F.; PRADO, N. R. T. do; CARVALHO, D. A. de; CARVALHO, G. A. de. Evaluation of the antifungal activity by plant extracts against Colletotrichum gloeosporioides Penz. Ciência e Agrotecnologia. Lavras, v.32, n.2, p.420-428, mar./abr., 2008.

SHARMA, S. B.; MOHIUDDIN, M.; JAIN, K. C.; REMANANDAN, P. Reaction of pegeonpea cultivars and germoplasm accessions to the root-knot nematode, Meloidogyne javanica. Journal of Nematology, Ames, v. 26, n. 1, p. 644-652, 1994.

SILVA, G. H. Purificação e caracterização de substâncias do metabolismo de fungos tóxicas a Meloidogyne incognita. 2001. 74 p. Dissertação (Mestrado em Agroquímica e Agrobioquímica) Universidade Federal de Lavras, Lavras, 2001.

TAKASUGI, M.; YACHIDA, Y.; ANETAI, M.; MASAMUNE, T.; KEGASAWA, K. Identification of asparagusic acid as a nematicide occurring naturally in the roots of asparagus. Chemistry Letters, Toquio, p. 43-44, 1975. 